\title{
Meteorological context of the onset and end of the rainy season in Central Amazonia during the GoAmazon2014/5
}

\author{
Jose A. Marengo ${ }^{1}$, Gilberto F. Fisch ${ }^{2}$, Lincoln M. Alves ${ }^{3}$, Natanael V. Sousa ${ }^{3}$, Rong Fu ${ }^{4}$, and Yizhou Zhuang ${ }^{4,5}$ \\ ${ }^{1}$ Centro Nacional de Monitoramento e Alerta de Desastres Naturais (CEMADEN), São Jose dos Campos, São Paulo, Brazil \\ ${ }^{2}$ Instituto de Aeronáutica e Espaço/Centro Tecnológico Aeroespacial (IAE/CTA), São Jose dos Campos, São Paulo, Brazil \\ ${ }^{3}$ Centro de Ciência do Sistema Terrestre/Instituto Nacional de Pesquisas Espaciais (CCST INPE), São Jose dos Campos, \\ São Paulo, Brazil \\ ${ }^{4}$ Department of Atmospheric and Oceanic Sciences, University of California, Los Angeles, California, USA \\ ${ }^{5}$ Department of Atmospheric and Oceanic Sciences, School of Physics, Peking University, Beijing, China \\ Correspondence to: Jose A. Marengo (jose.marengo@cemaden.gov.br)
}

Received: 10 January 2017 - Discussion started: 15 February 2017

Revised: 10 May 2017 - Accepted: 23 May 2017 - Published: 26 June 2017

\begin{abstract}
The onset and demise of the rainy season in Amazonia are assessed in this study using meteorological data from the GoAmazon experiment, with a focus on the 20142015 rainy season. In addition, global reanalyses are also used to identify changes in circulation leading to the establishment of the rainy season in the region. Our results show that the onset occurred in January 2015, 2-3 pentads later than normal, and the rainy season during the austral summer of 2015 contained several periods with consecutive dry days in both Manacapuru and Manaus, which are not common for the wet season, and resulted in below-normal precipitation. The onset of the rainy season has been strongly associated with changes in large-scale weather conditions in the region due to the effect of the Madden-Julian Oscillation (MJO). Regional thermodynamic indices and the height of the boundary layer did not present a significant difference between the onset and demise of the wet season of 2015 . This suggests that local changes, such as those in the regional thermodynamic characteristics, may not have influenced its onset. Thus, variability of the large-scale circulation was responsible for regional convection and rainfall changes in Amazonia during the austral summer of 2014-2015.
\end{abstract}

\section{Introduction}

The Amazon region represents one of the main convective centers in the world tropics, together with equatorial Africa and the Indian monsoon regions. In this region, tropical convection is one of the key processes regulating the climate system, and it plays an important role in the maintaining the water and energy balance while also helping the development of the zonal and vertical components of the circulation. The interannual rainfall variability in the Amazon basin is linked to variations of sea surface temperatures (SSTs) in both tropical Pacific and Atlantic oceans (Marengo, 1992; Ronchail et al., 2005; Yoon and Zeng, 2010; Marengo and Espinoza, 2015, and references quoted therein). Indeed, previous studies have documented that warm conditions in the equatorial Pacific (e.g., El Niño events) produce a rainfall deficit in Amazonia, which can cause extreme drought periods, as observed in 1926, 1983, 1997-1998 and 2010 (Williams et al., 2005; Marengo et al., 2008, 2011; Espinoza et al., 2011; Marengo and Espinoza, 2015). In the early 21st century, large-scale extreme seasonal events, such as extreme droughts in 2005, 2010 and 2015 and floods (2009, 2012, 2014) have affected the Amazon region. Rainfall anomalies were the consequence of circulation changes forced by anomalous warming or cooling of the tropical Pacific and/or tropical North or South Atlantic oceans, as documented by Marengo and Espinoza, 2015, and references quoted therein). 
In sum, while we had several droughts in Amazonia linked to El Niño, as in 1925, 1983, 1987, 1998 and recently in 2015-2016, some other drought events were reported in 1963 and 2005, which were not related to El Niño but to a warmer tropical North Atlantic. When the tropical North Atlantic is warmer than the tropical South Atlantic, the intertropical convergence zone is displaced northward, leaving less rainfall in the region. This may happen with an El Niño (1983, 1998) or without an El Niño (2005). Every drought in Amazonia is different in terms of spatial coverage.

The occurrence of extreme weather and drought and flood events has changed people's perception of climate extremes - as happened after those extensive droughts and flooding. In Amazonia, the population perceives drought as anomalously low river levels during the peak season May-July, more than as low rainfall during the peak season in February-April. Drought is an impact while deficient rainfall is the climatic forcing of this impact. However, in terms of some ecological impacts or for agriculture, drought may be more related to deficient rainfall during the peak of the rainy season. Drought and floods and their impacts on natural and human systems in the region show the vulnerability of residents and ecosystems to the occurrence of hydrometeorological extremes in the region.

Rainfall in the Amazon basin is mainly supported by the moisture flux from the equatorial Atlantic associated with the trade winds (Angelini et al., 2011). However, the Amazon climate has to be seen as coupled interactive atmosphereocean-land phenomena (Runyan et al., 2012), and current research (Makaireva et al., 2013) suggests that land surface processes may play a comparable part, equal in importance to that of the ocean, and have explored the role of the forest in the recycling of water, suggesting an active role of the vegetation in the regional water cycle. Previously, Salati and Vose (1984) calculated this influence to be $50 \%$ for inland Atlantic moisture and $50 \%$ for local recycling by evapotranspiration and precipitation, using isotope techniques. An intensification of the hydrological cycle in Amazonia over the last two decades has been identified by Gloor et al. (2013), who attributed it to an increase in atmospheric water vapor coming from a warmer tropical Atlantic. This is consistent with a positive trend in precipitation in the northwestern Amazon since 1990, and is also reflected water levels at Manaus and in the Amazon discharges at Óbidos (Marengo and Espinoza, 2015).

Variability of wet and dry seasons suggests that the onset and demise of the wet and dry seasons and thus the length of the wet and dry season are changing with time (Marengo et al., 2012; Marengo and Espinoza, 2015). Observational studies in southern Amazonia suggest that the dry season has increased in length by about 1 month since the 1970s (Marengo et al., 2011; Fu et al., 2013). Furthermore, the length of the dry season also exhibits interannual and decadal-scale variations linked either to natural climate variability, or, as suggested by Wang et al. (2011), due to the results of the influence of changes in land use in the region. While it is important to know the future characteristics of the total rainy-season rainfall, it is also important to highlight the urgency of improving our understanding and capability to detect and predict the rainy season onset and demise, as well as the variability of the wet and dry seasons, not just through model experiments but also through observational analysis. The droughts of 2005 and 2010 and their impacts on humans and on the tropical forest have been characterized by late onsets of the rainy season and/or longer dry seasons (Marengo et al., 2011; Marengo and Espinoza, 2015). During the recent El Niño in 2015-2016, rainfall over central-northern Amazonia has been below normal (by approximately 200 $300 \mathrm{~mm}$ for the wet season), and this contributed to an extensive drought and subsequent problems in the hydrology of the region, as well as an increased number of fires there (CPTEC - www.cptec.inpe.br). The length of the dry season has a large temporal and spatial variability, and is strongly associated with dry conditions that may impact the occurrence of fires and their release of carbon and aerosols, as well as affecting human systems (Aragão et al., 2014; Martin et al., 2016).

Various studies have discussed observational and modeled aspects of the onset and demise of the rainy season in Amazonia using a variety of climatic indicators, such as rainfall, outgoing long-wave radiation or dynamic fields (e.g., Kousky, 1988; Marengo et al., 2001, 2012; Fu et al., 1999; Liebmann and Marengo, 2001; Gan et al., 2004; Wang and Fu, 2002; Silva and Carvalho, 2007; Raia and Cavalcanti, 2008; Marengo and Espinoza, 2015). However, modeling work still shows uncertainties in the representation of the onset of the rainy season. This may be due to the poor representation of clouds and land surface-atmosphere interactions or due to the role of aerosols and other particles, which are still not well represented in models.

Moisture transport across the Equator and its variations could influence convection and thus the wet-season onset (Rao et al., 1996; Marengo et al., 2001; Wang and Fu, 2002; Alves, 2016). Li and Fu (2006) showed that weak and infrequent extratropical cold front penetrations during the transition season also contribute to a delay of the wet-season onset. However, the complexity of the relationship between ENSO, Atlantic SSTs and the onset of the wet season over the southern and central Amazon remains unclear. Butt et al. (2011) identify significant differences in the onset of the rainy season in Rondonia between 1970 and 2000, due to land-use changes in the region. However, the uncertainties of the attribution of these extremes and their variations to natural and human influences are still great. This highlights the urgency of understanding the underlying causes of the onset and demise of the rainy season and our ability to predict them. Furthermore, evidence of the possible role of human influences (deforestation, increase of greenhouse gases and aerosol released due to biomass burning or urban pollution) on rainfall and river variability has started to appear in 

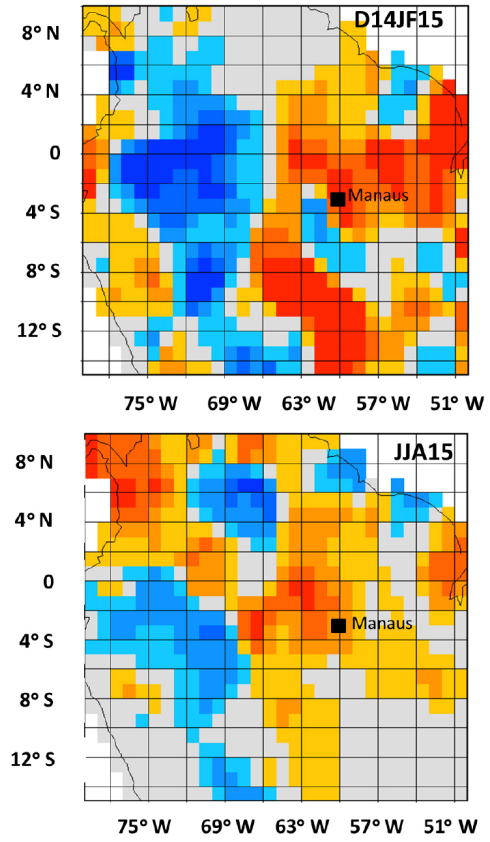

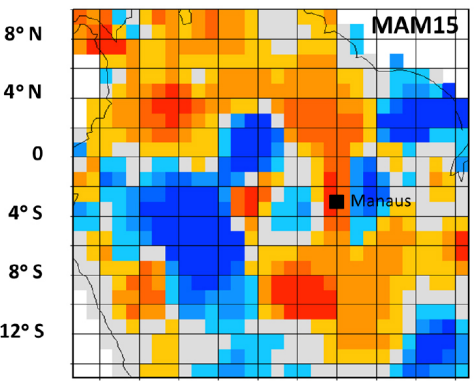

$75^{\circ} \mathrm{W} \quad 69^{\circ} \mathrm{W} \quad 63^{\circ} \mathrm{W} \quad 57^{\circ} \mathrm{W} \quad 51^{\circ} \mathrm{W}$

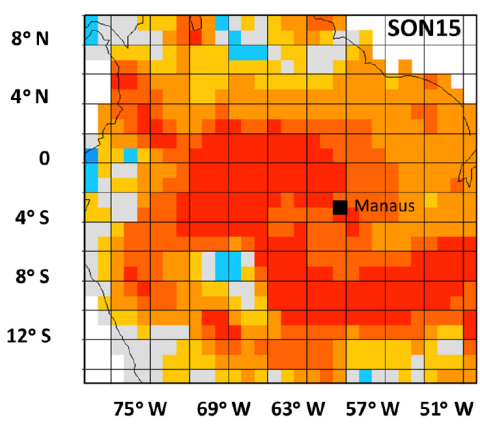

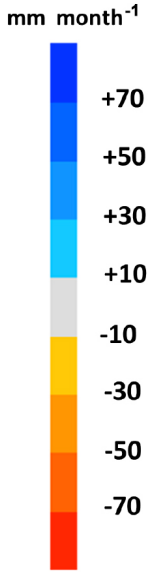

Figure 1. Rainfall anomaly (mm month ${ }^{-1}$ ) for 3-month periods from December 2014-May 2015 to September-November 2015. Data come from GPCC and anomalies are relative to the 1951-2001 climatology. Black square indicates the location of Manaus.

the literature recently (Alves, 2016; Spracklen and GarciaCarreras, 2015; Magrin et al., 2014; Zhang et al., 2009).

Increasing aerosol concentrations can have substantial impacts on spatial and temporal rainfall patterns in the Amazon (e.g., Martins et al., 2009a; Reutter et al., 2009; Pöhlker et al., 2016). The initial work by Andreae et al. (2004) suggest that aerosols from biomass burning in Amazonia may delay the onset of the rainy season in southern Amazonia, but not much is known on the possible role of aerosols from urban areas in rainfall and the water cycle in the Amazon region. Previous studies have found that cloud microphysical properties, cloud cover, precipitation, lightning and regional climate over the Amazon basin can be significantly affected by aerosol particles (Li et al., 2006; Altaratz et al., 2010; Koren et al., 2012; Gonçalves et al., 2015; Wang et al., 2016).

In this paper, we use data from the GoAmazon and CHUVA experiments during 2014-2015 as well as global reanalyses to investigate regional and large-scale circulation and rainfall patterns during the onset and demise of the rainy season. Emphasis is on the identification of large-scale patterns leading to the onset and demise of the rainy season in the Manaus region in central Brazilian Amazonia in both years. We have taken advantage of the high resolution of surface meteorological data collected during these two field experiments as part of GoAmazon in 2014-2015, and also the presence of El Niño during summer of 2015, to investigate daily and diurnal rainfall variability. We also investigated the large-scale and regional circulation patterns linked to rainfall variability in those regions. With the GoAmazon data we have investigated the onset and demise of the rainy season of 2014-2015, as well as convection and the planetary boundary layer (PBL) heights in some sites near Manaus, where thermodynamic indices were calculated to identify the transition regimes before and after both the onset and demise of the rainy season.

\section{Methods}

The data used for this study come from the GoAmazon Project (Martin et al., 2016), designed to study some of the characteristics of the rainy season in Amazonia, such as onset and demise of dry and wet seasons, and we have used some of the CHUVA and GoAmazon 2014/5 rainfall and surface and upper-air meteorological data available from 2014 to 2015. The expression green ocean (Go) was introduced by Williams et al. (2005) due to the similarities in aerosol particle concentrations and cloud microphysics between the Amazon basin and remote oceanic regions during clean periods of the wet season. Observations and data from modeling work from the GoAmazon Experiment (GoAmazon 2014/5 http://campaign.arm.gov/goamazon2014/) were collected in the central region of Amazonia near Manaus from 1 January 2014 through 31 December 2015. More details on the nature and objectives of GoAmazon 2014/5 can be found in Martin et al. (2016).

As described by Machado et al. (2014), the CHUVA project (CHUVA meaning "rain" in Portuguese) is the acronym for the Cloud Processes of the Main Precipitation 


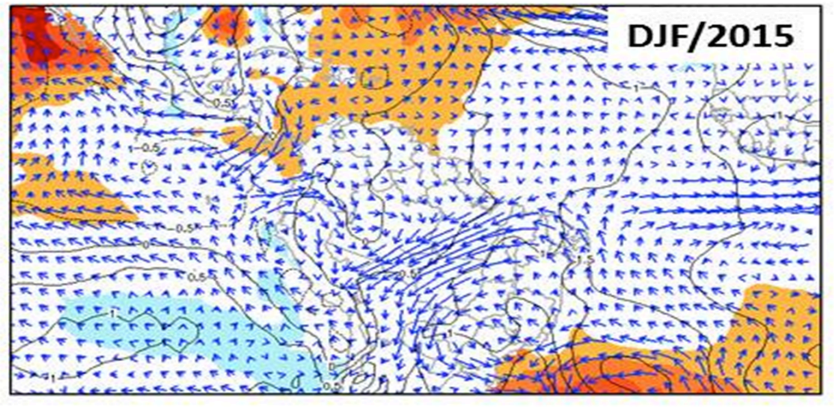

$\overrightarrow{100}$

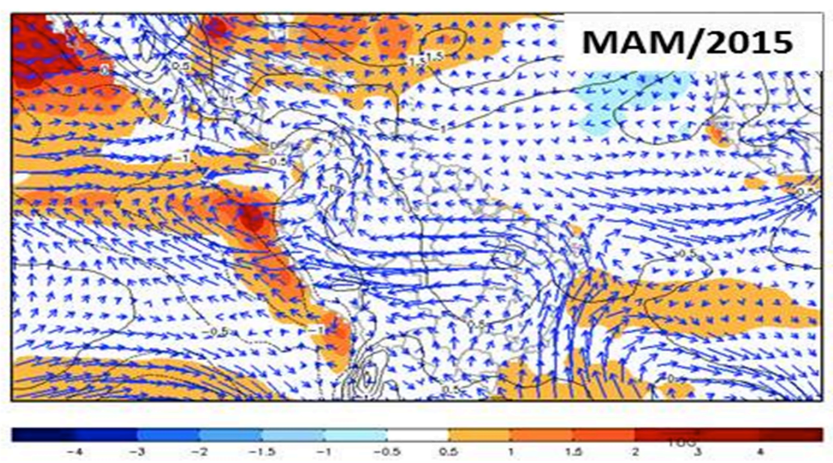

Figure 2. Seasonal SST anomalies $\left({ }^{\circ} \mathrm{C}\right)$, SLP anomalies (hPa) and anomalies of vertically integrated moisture transport (vectors) from the surface to $500 \mathrm{hPa}$ in South America from December 2014 to May 2015. SST and circulation anomalies correspond to the 19612012 long-term mean. The bar at the bottom of the panel shows the scale of the SST anomalies. The vector at the bottom of the panel shows the scale of the moisture transport $\left(\mathrm{kg}^{-1} \mathrm{~m} \mathrm{~s}^{-1}\right)$. Black full lines show SLP anomalies (hPa).

Systems in Brazil: A Contribution to Cloud-Resolving Modelling and to Global Precipitation Measurement (GPM). It began in 2010 and has conducted five field campaigns with the last experiment having been held in Manaus as part of the GoAmazon 2014/5 experiment. CHUVA's main scientific motivation is to contribute to the understanding of cloud processes, which represent one of the least-understood components of the climate system. Field data from the CHUVA and GoAmazon 2014/5 campaigns are used to improve our understanding of the dynamics of the onset of the rainy season and the characteristics of the dry season during that year. The data turned out to be useful since we now had the possibility of identifying the onset the rainy season over central Amazonia using high-resolution meteorological data collected near Manaus since the end of 2013. In addition, we analyze ground-based remotely sensed data (ceilometer) to identify changes in the PBL during the onset and demise of 2014-2015 rainy season. Wind, outgoing long-wave radiation (OLR) and sea surface temperature data from the National Center for Environmental Prediction (NCEP) Climate Prediction Center (CPC) are used to examine the influence of atmospheric and oceanic conditions on the onset and demise of the rainy seasons.

Rainfall data (at diurnal and daily levels) come from the Brazilian Meteorological Service (INMET) station at Manaus $\left(3.11^{\circ} \mathrm{S}, 59.95^{\circ} \mathrm{W}\right)$ and at Manacapuru from the University of the State of Amazonas UEA (70 km upwind of Manaus: $03.05^{\circ} \mathrm{S}, 60.00^{\circ} \mathrm{W}$ ). The pentad of the onset and end (or demise) of the rainy season in Amazonia was calculated using the criterion of rainfall accumulation data, defined by Liebmann and Marengo (2001) and adapted by Bombardi and Carvalho (2009) using gridded rainfall data. This criterion was applied to data from the Manaus and Manacapuru (nearby Manaus) rainfall stations from the GoAmazonCHUVA network during 2014-2015, by averaging all available data for a given day from those two stations onto a $1.0^{\circ}$ grid. The availability of data from a large number of stations in a grid box as allows a more regional view compared to single station data.

Additional datasets for regional rainfall analyses during those two rainy seasons come from the NCEP-NOAA CPC (www.ncep.noaa.gov) and from the Global Precipitation Climatology Center (GPCC) gauge-based gridded precipitation dataset, available for the global land surface only. The GPCC datasets are available at spatial resolutions of $1.0^{\circ}$ latitude $\times 1.0^{\circ}$ longitude as mean monthly precipitation totals and anomalies relative to the 1951-2000 mean.

Once the pentad of the onset was identified for Manaus and Manacapuru, various analyses are performed for the periods before and after the onset, in order to identify and understand possible shifts in atmospheric circulation and energy fluxes and characteristics of the PBL and thermodynamic indices convective available potential energy (CAPE) and convective inhibition energy (CIN) that would favor the establishment of the onset of the rainy season of 2014-2015. CAPE and CIN values were computed using the original variables for the $500 \mathrm{~m}$ thick mixing-layer parcel. The height of the PBL was derived from a ceilometer installed at the T3 site in Manacapuru and its hourly values were computed for pentads and post-onset and post-demise of the rainy season in 2014-2015. The latent (LE) and sensible (H) turbulent heat fluxes as well as the Bowen ratio were derived from these fluxes at the T3 site and the EMBRAPA Flux for 2014-2015 in order to quantify their values before, during and after the onset and end (or demise) of the rainy season, so we could investigate the energy partition and convective processes that accompany the evolution of the rainy season during the days of the GoAmazon campaign. More details about the instrumentation used can be found in Machado et al. (2014), Martin et al. (2016) and Wang et al. (2016). 


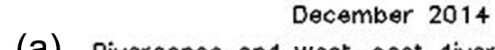

(a) Divergence and west-east divergent circulation
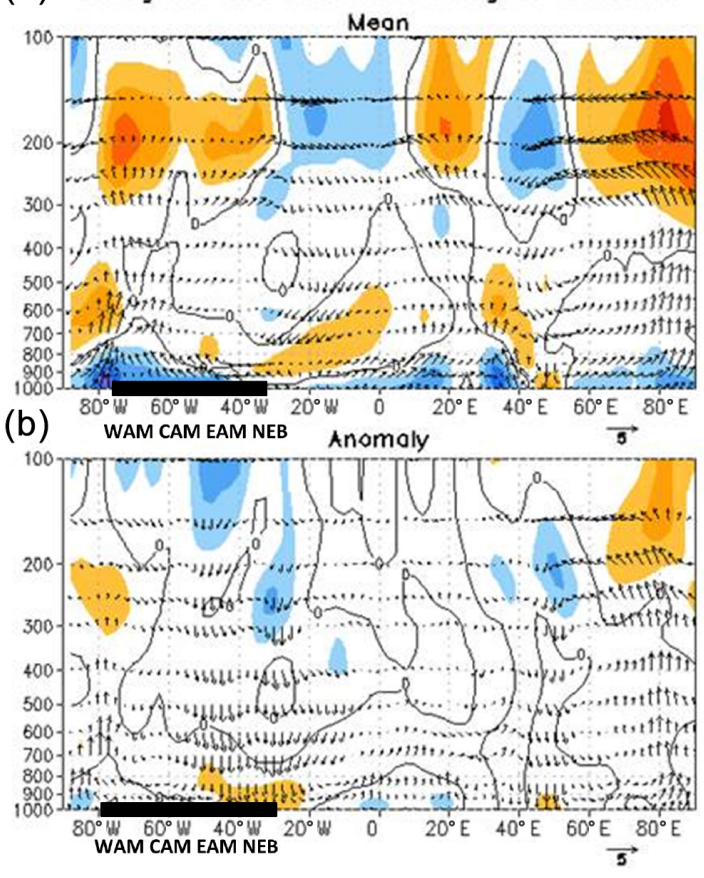

WAM- Western Amazonia

CAM-Central Amazonia (near Manaus)

EAM-Eastern Amazonia

NEB- Northeast Brazil

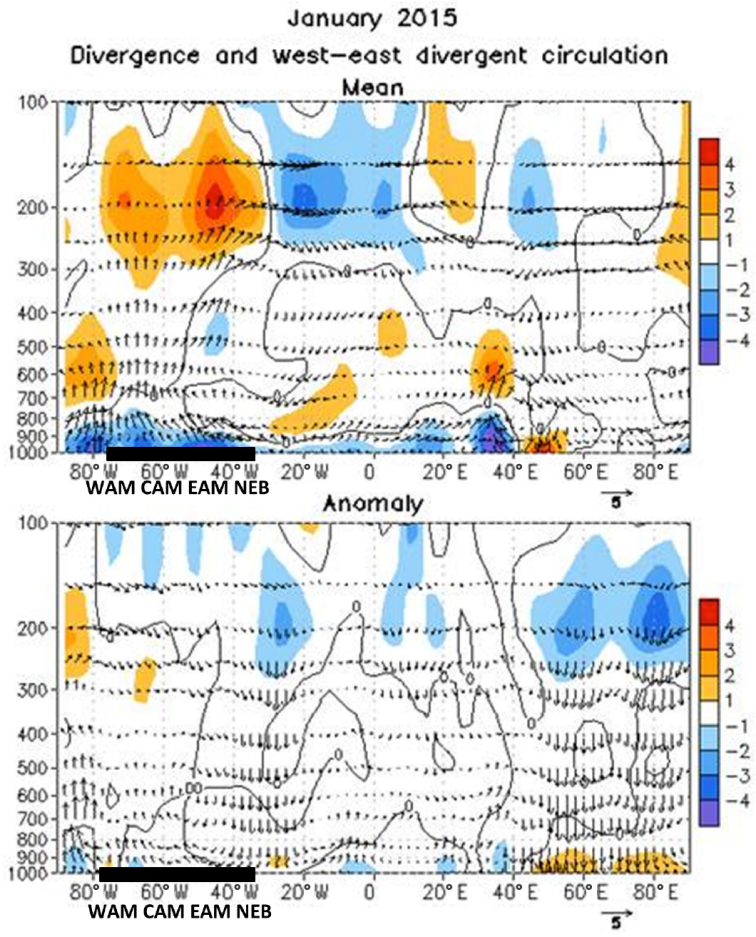

Figure 3. Pressure-longitude section $\left(80^{\circ} \mathrm{W}-100^{\circ} \mathrm{E}\right)$ of the mean (a) and anomalies (b) of divergence (contour interval is $\left.1 \times 10^{-6} \mathrm{~s}^{-1}\right)$ and divergent circulation between $5^{\circ} \mathrm{N}$ and $5^{\circ} \mathrm{S}$. The divergent circulation is represented by vectors of combined vertical velocity and the divergent component of the zonal wind. Red shading and solid contours denote divergence (a) and anomalous divergence (b). Blue shading denotes convergence (a) and anomalous convergence (b). Anomalies are departures from the 1981-2010 long-term mean.

\section{Results}

\subsection{Characteristics of the 2014-2015 rainy season in Amazonia}

The mean climatic features of the Manaus region, where the peak of the rainy season occurs around March-May, are described elsewhere (Greco et al., 1990; Cohen et al., 1995; Machado et al., 2014; Martin et al., 2016). The GPCC rainfall (Fig. 1a-d) shows rainfall anomalies from December 2014February 2015 (representing the wet season) to SeptemberNovember 2015. Over central and eastern Amazonia in the wet season, rainfall was about $80-90 \mathrm{~mm} \mathrm{month}^{-1}$ below normal, while over western Amazonia rainfall was about 50$90 \mathrm{~mm} \mathrm{month}^{-1}$ above normal. For the September-OctoberNovember period the rainfall was well below normal (by around $90 \mathrm{~mm} \mathrm{month}^{-1}$ ), in almost all of Amazonia. This is a signal of the impacts of El Niño 2015-2016, which was under development in the tropical Pacific since the middle of 2015 (Fig. 2). Warm surface waters $\left(1.5-2.5^{\circ} \mathrm{C}\right)$ were detected along the equatorial Pacific in the period from March to May 2015. This 2015-2016 drought caused the longest fire season of the 21 st century, with 5 months exceeding 10000 fire detections and the largest number of active fire occurrences per square kilometer of deforested land (Aragão et al., 2014). This combination of a longer dry season, more frequent extreme droughts and an increased risk of fire could play a critical role in a future Amazon rainforest dieback in spite of the increased resilience of tropical forests in an elevated atmospheric $\mathrm{CO}_{2}$ environment (Huntingford et al., 2013).

As to regional-scale circulation features, the December 2014 to January-February 2015 season did not show signals of El Niño in the tropical Pacific, but the warm surface waters were already present during March- April-May (MAM) 2015 (Fig. 2). This warming increased continuously until March 2016, indicating the intensification of El Niño in 2015-2016, with warm surface water $\left(3-4{ }^{\circ} \mathrm{C}\right.$ above normal) over the equatorial eastern Pacific by the austral summer of 2016 (www.cptec.inpe.br). The low-level circulation anomaly vectors show small southerly wind anomalies, suggesting weakened northerly flow over the tropical North Atlantic and Amazon sectors (Fig. 2). Along the Equator, Fig. 2 shows that there are westerly anomalies, but these are away from the coast (looking at December-January-February, 


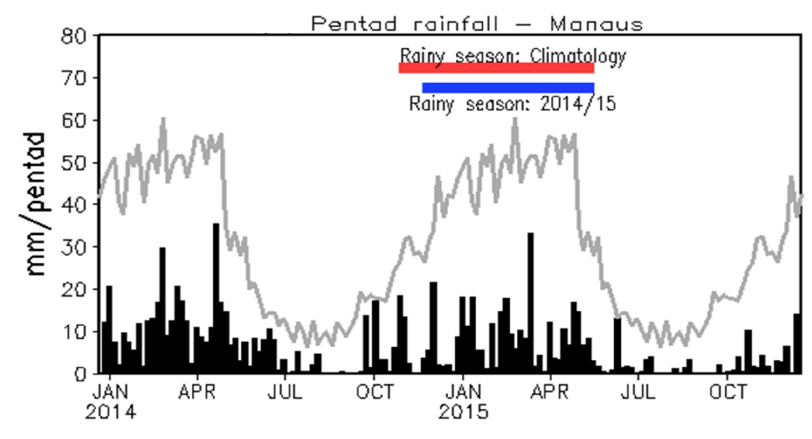

Figure 4. Pentad rainfall ( $\left.\mathrm{mm} \mathrm{pentad}^{-1}\right)$ at Manaus (INMET site) from January 2014 to December 2015. The red bar shows the climatological occurrence of the onset and end of the rainy season, while the blue bar indicates the onset and end for 2014-2015. The grey line is the climatological annual cycle of pentad mean precipitation.

DJF). Along the Atlantic coast and north of the Equator, however, the anomalies are near zero. There are huge positive transport anomalies from the Equator into the southern Amazon, which are consistent with above-normal precipitation to the west (south of the Equator), since there appears to be anomalous convergence of moisture there (Fig. 2a). An analysis of the near-surface and upper-air circulation discussed previously can provide a better idea of the regional eastwest circulation of the region during December 2014 and January 2015. The east-west vertical cross-section along the Equator $\left(5^{\circ} \mathrm{N}-5^{\circ} \mathrm{S}\right)$ in Fig. 3 shows upward-motion anomalies over western Amazonia during both summer months while reduced convection and downward motion with subsidence is found over central Amazonia, eastern Amazonia and northeastern Brazil. The latter region has been experiencing a record drought since 2011 (Marengo et al., 2016). These circulation anomalies are consistent with negative rainfall anomalies over central Amazonia near the Manaus region. Therefore, interannual variations of the wet-season onset in the Amazon appear to be influenced by changes in large-scale and regional circulation over the tropical Atlantic and Pacific sectors.

\subsection{Daily rainfall variation and characterization of the onset and demise of the rainy season during 2014-2015}

In order to verify the variability in rainy-season characteristics, the onset and demise of the rainy season over Manaus has been defined following Liebmann and Marengo (2001) using daily precipitation data from Manaus station for the period 1961-2015. Using this methodology, the climatological onset is detected around pentad 64 (12-16 November) and the demise of the rainy season around pentad 29 (2125 May). Figure 4 plots the pentad rainfall recorded during 2014-2015 for Manaus station. It also plots the annual precipitation climatology of the pentad cycle and the onset and demise of the rainy season. The data showed anoma-

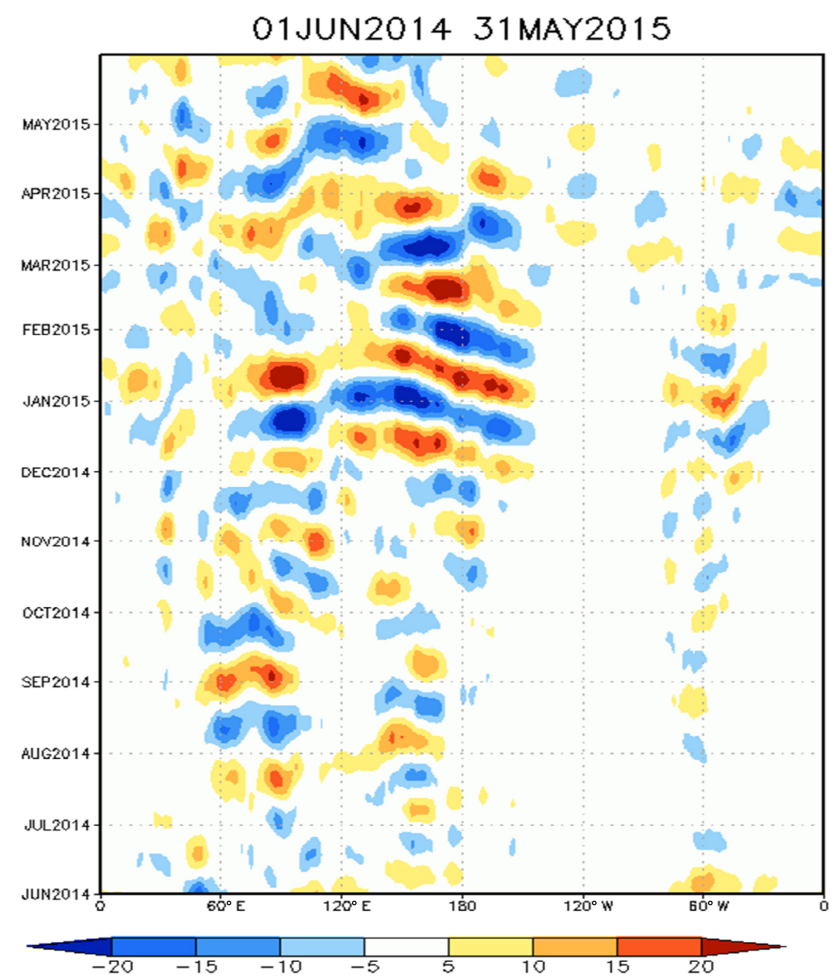

Figure 5. Hovmoller diagram of 30-60-day filtered OLR anomalies $\left(\mathrm{W} \mathrm{m}^{-2}\right)$ along the Equator $\left(5^{\circ} \mathrm{N}-5^{\circ} \mathrm{S}\right)$ during the period of June 2014 to May 2015.

lously late onset (around the pentad 69: 7-11 December) in 2014-2015. The demise of the rainy season occurs around pentad 29 (21-25 May), which agrees with the climatological date, giving a shorter-than-normal rainy season. In addition, the data showed that the Manaus station experienced reduced rainfall totals compared with climatology, with some dry spells.

As seen in the previous section, despite the oceanic and atmospheric conditions in the equatorial Pacific (El Niño $1+2$ and 3) which show ENSO-neutral conditions during the period before the onset, it is noted that the patterns of regional precipitation distribution over central and eastern Amazonia were consistent with a distinct phenomenon that caused changes in weather conditions in the region, for example, the Madden-Julian Oscillation (MJO; Madden and Julian, 1994; Liebmann et al., 1999; De Souza and Ambrizzi, 2006; Alvarez et al., 2015). This is shown in Fig. 5 in the time diagram of OLR anomalies between $5^{\circ} \mathrm{N}$ and $5^{\circ} \mathrm{S}$ over the globe in 2014 and 2015.

It is observed that from July through late October 2014 the intraseasonal signal became less coherent, with a weaker anomaly field, and is inconsistent with a canonical El Niño signal. The pattern became more organized during late November as the MJO strengthened, as indicated by eastward propagation of alternating anomalies into January 2015. At this time, the MJO may have contributed to enhanced rain- 


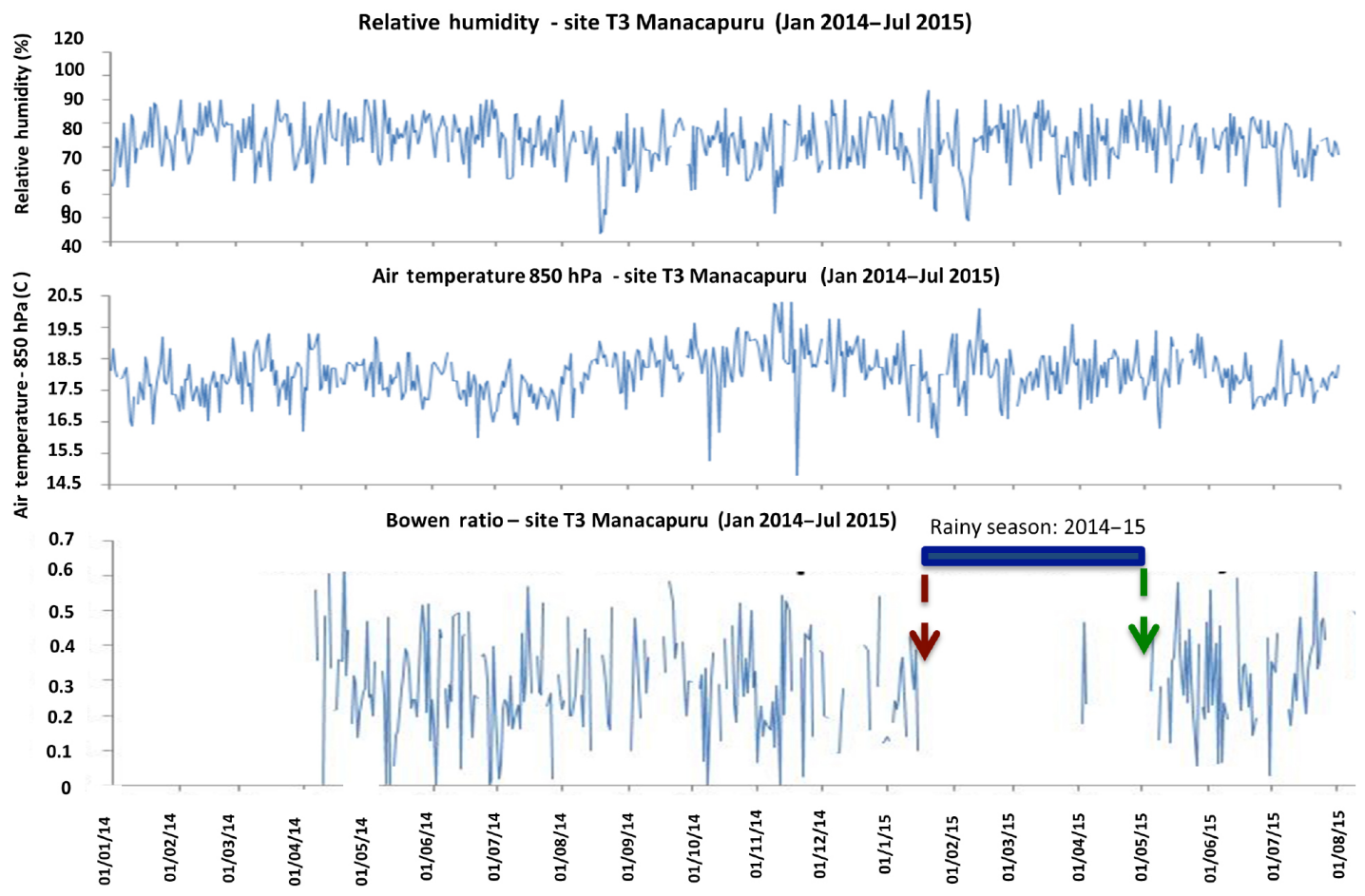

Figure 6. Daily variation of relative humidity $(\%), 850 \mathrm{hPa}$ air temperature $\left({ }^{\circ} \mathrm{C}\right)$ and Bowen ratio at the T3 Manacapuru site, from January 2014 to July 2015. The blue bar indicates the onset and end of the rainy season for 2014-2015. No Bowen ratio data were available during some days between January 2014 and July 2015.

fall and the onset of the rainy season for portions of Amazonia, as indicated by negative OLR anomalies (blue shading) favoring conditions for precipitation around $60^{\circ} \mathrm{W}$.

This fact was reflected in the temporal distribution of rainfall (Fig. 4), which depicts the regional frequency of precipitation in this period. In summary, the phases of MJO-associated OLR anomalies were evident throughout the equatorial region, and in particular over the central and eastern Amazon. This suggests that the negative MJO phase in mid-January may have contributed to favouring conditions to enable the convection and the onset of the rainy season from pentad 6. This is consistent with other atmospheric mechanisms on a local scale, for example, the near-surface local circulation and thermodynamic patterns.

Broadly speaking, the influence of the MJO on precipitation over the tropics occurs by eastward propagation of Rossby wave trains from the tropical Pacific Ocean (Muza et al., 2009). Previous observational and modeling studies generally indicated that the MJO and ENSO have a decadal variation and seasonal dependence (Hendon et al., 2007); however, these have not been well identified due to their nonlinear nature. These studies also show significantly lagged correlations between MJO and ENSO indices. Despite this, Shimizu et al. (2016) recently examined the regional relationship between ENSO and MJO phases in climatological patterns of precipitation over South America. The results in- dicated that combined responses showed that precipitation is strongly influenced by the MJO phases rather than by ENSO conditions, especially during the austral summer. Thus, our results corroborate those of Shimizu et al. (2016), who observed the highest percentages of days with active MJO and increased rainfall occurring during El Niño and neutral year.

Figure 6 shows the daily variation of air temperature at $850 \mathrm{hPa}$, relative humidity and Bowen ratio at the T3 Manacapuru site. Wet conditions were consistent with higher relative humidity and lower temperatures, while dry spells occur with lower relative humidity and higher air temperatures. Before the onset we noticed a reduction in temperature and humidity, while it is hard to see any tendency of the Bowen ratio before the onset or after the demise of the rainy season. The latent heat fluxes over the land surface are important sources of atmospheric humidity during the initial stages of the transition season between dry and wet periods (Fu and $\mathrm{Li}, 2004)$. Together with changes in the onset of the rainy season, changes of dry season length may be key in favouring the present risk of fire. A high land-surface Bowen ratio during the preceding dry season would delay the subsequent wet-season onset in the southern Amazon (Fu and Li, 2004), and this may have been the case in the onset rainfall in 20142015. 

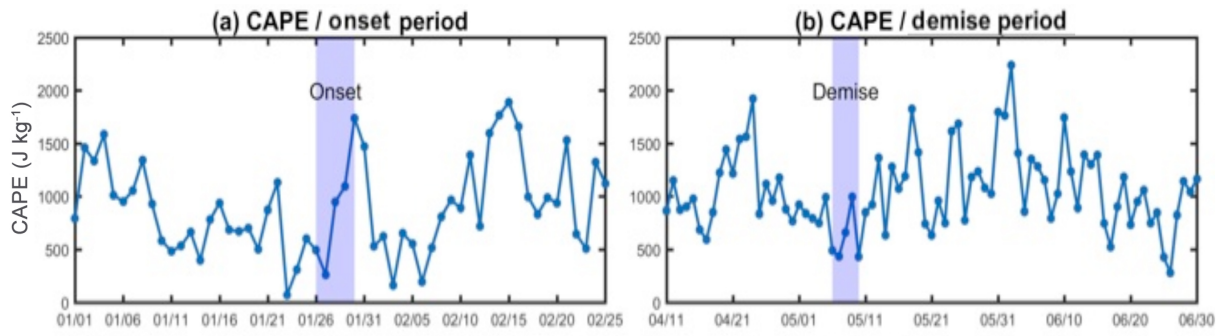

(c) $\mathrm{CIN} /$ onset period
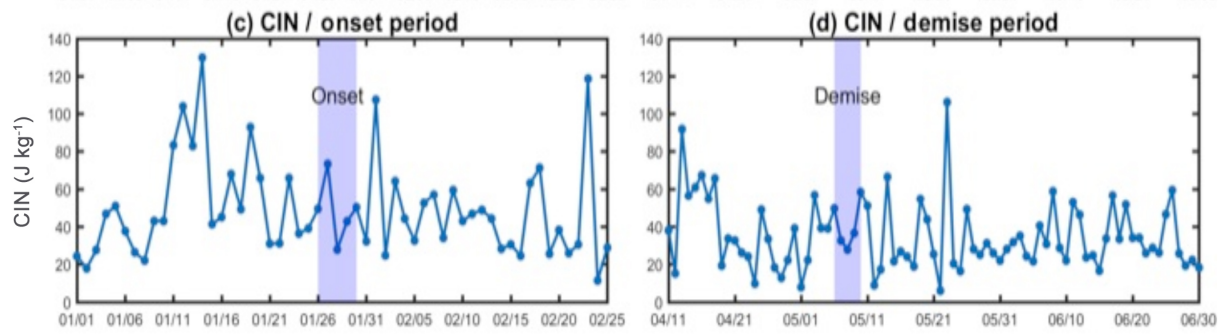

Figure 7. Daily variation of CAPE and CIN $\left(\mathrm{J} \mathrm{kg}^{-1}\right)$ from 1 January to 25 February 2015 (around the onset of the rainy season) and from 11 April to 30 June (around the demise of the rainy season) at Manaus. Pentads of the onset and demise are identified with blue vertical bars.

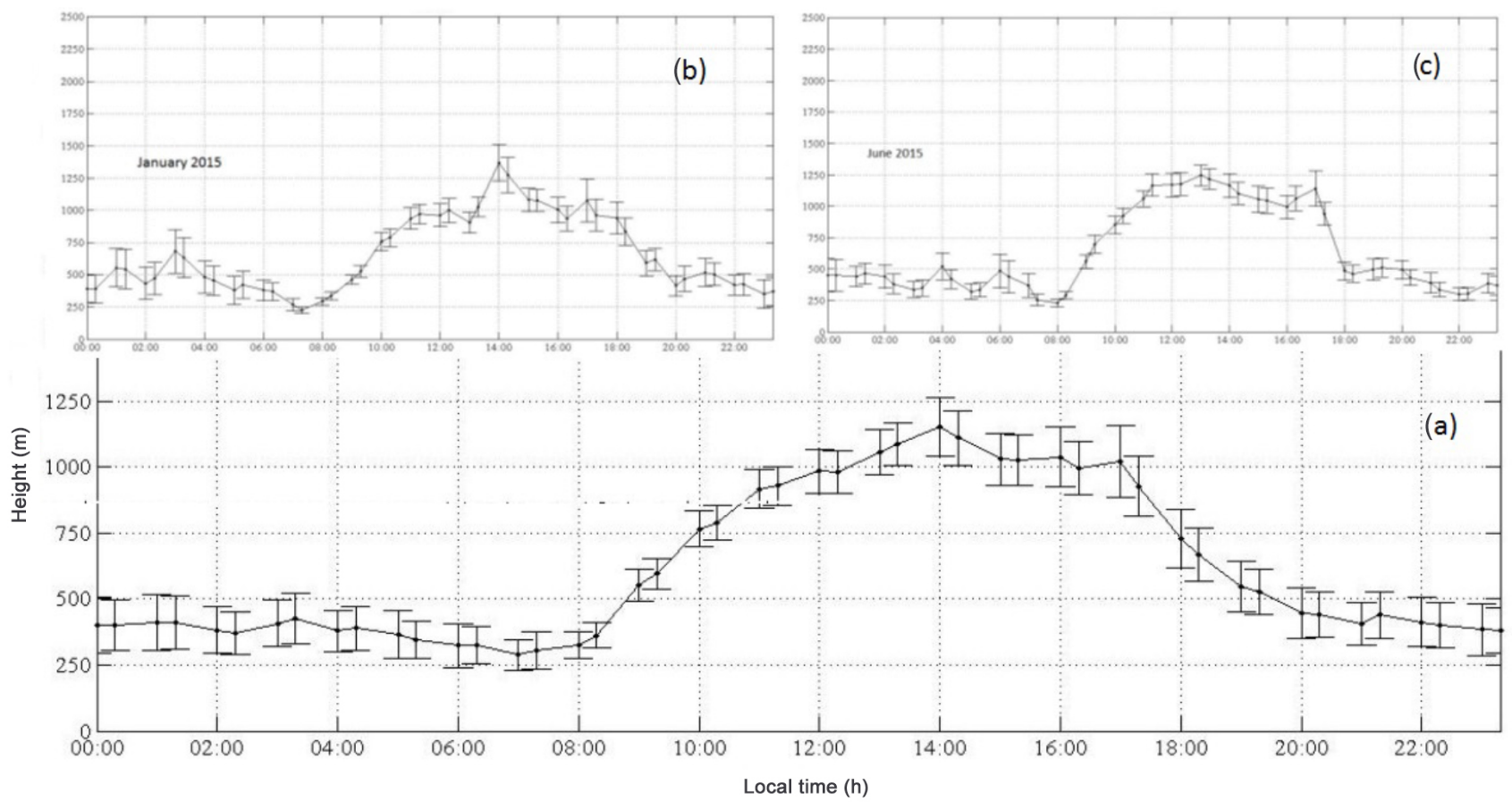

Figure 8. Diurnal cycle of the height of boundary (m) layer (average from 1 January up to 30 June 2015) (a), from January 2015 (b) and June 2015 (c).

\subsection{Thermodynamic indicators and PBL behavior during the onset and demise of the rainy season in 2014-2015}

Using the T3 radiosonde data, 1-day averages of CAPE and CIN (Fig. 7) were calculated for each profile and these in turn were averaged over pentads. One pentad was selected to encompass the onset of the rainy season and another its demise. The figure shows that CAPE and CIN are very noisy; hence, a two-sample $t$ test for daily average CAPE and CIN values during the rainy season (26 January 2015-10 May 2015) and before and after the rainy season (1 November 2014-25 January 2015 and 11 May-1 December 2015) was performed. Results suggest that both CAPE and CIN values change between the two periods (during the rainy season and before and after the rainy season), indicating a difference significant $t$ the $5 \%$ level in CAPE and CIN between the days with and without deep convection. 
The diurnal cycle of the heights of the PBL was computed with the ceilometer installed at the T3 site. Figure 8 a shows the composite PBL diurnal cycle for the wet season 20142015. The PBL height remained stationary at around 300$400 \mathrm{~m}$ during nighttime (nocturnal boundary layer), then increased during daytime (convective boundary layer), and reached its maximum $(1100-1200 \mathrm{~m})$ in the early afternoon (14:00 LT). This pattern is consistent with the previous values obtained for Amazonia for the wet season (Fisch et al., 2004). There is no signal of the anomalous wet season in the PBL heights. Individual diurnal cycles for other months (Fig. 8b, c) also did not present a significant difference between the onset and demise of the wet season of 2015.

A moistening of the planetary boundary layer and a lowering of the temperature at its top may reduce CIN and control the conditioning of the large-scale thermodynamics prior to onset (Fu et al., 1999). In addition, $\mathrm{Li}$ and $\mathrm{Fu}$ (2006) found that the main increase in CAPE and reduction in CIN occur prior to the rainy season onset, although in the tropical atmosphere a decrease CAPE often exists in the absence of deep convection (Williams and Renno, 1993).

\section{Conclusions}

The onset of the rainy season in Amazonia is assessed in this study based on changes in precipitation, large-scale synoptic flow fields and thermodynamic parameters during the GoAmazon experiment.

The focus was on the 2014-2015 rainy seasons using the available climatic data from the GoAmazon field experiment as well as other sources. From our results, based on the analysis of daily data from various sites of the experiment, it was observed that onset of the rainy season of 2014-2015 was delayed, occurring in January 2015, 2-3 pentads later than normal. However, during that rainy season there were several consecutive dry days between December 2014 and March 2015 in both Manacapuru and Manaus, which are not common in the wet season, and thus determine below-normal precipitation. The onset of the rainy season has been strongly associated with changes in large-scale weather conditions in the region due to the effect of the MJO. Thus, the MJO may have contributed to enhancing rainfall in portions of Amazonia, as indicated by increased convection favouring conditions for precipitation around $60^{\circ} \mathrm{W}$.

The CAPE and CIN show a significant change between the days with and without deep convection. However, while there is an increase in CAPE before the onset and a decrease after the demise, no clear change of CIN during the onset period is detected. The diurnal cycle of the heights of the PBL also does not show any signal of the anomalous wet season and the individual PBL diurnal cycles did not present a significant difference between the onset and demise of the wet season 2015. While one of the main objectives of the GoAmazon Experiment was to assess the influence of the air pollution from the city of Manaus upon the rainy season in that region, the possibility that regional characteristics or pollution could have had an effect on the onset of the rainy season could not be ruled out. Our conclusion is that variability of the largescale circulation was responsible for regional convection and rainfall changes in Amazonia during the austral summer of 2014-2015.

Data availability. Go Amazon 2014/5 data come from the GoAmazon Experiment website (http://campaign.arm.gov/ goamazon2014/); atmospheric circulation data come from CPTEC - www.cptec.inpe.br; CPC NCEP - www.cpc.ncep.noaa.gov. Rainfall data come from CPTEC, INMET - www.inmet.gov.br and GPCC - www.dwd.de/EN/ourservices/gpcc/gpcc.html.

Competing interests. The authors declare that they have no conflict of interest.

Acknowledgements. Data were obtained from the Atmospheric Radiation Measurement (ARM) Program sponsored by the U.S. Department of Energy, Office of Science, Office of Biological and Environmental Research, Climate and Environmental Sciences Division. This work was supported by FAPESP/DOE/FAPEAM GoAmazon grant 2013/50538-7 and FAPESP grant no. 2015/50122-0 and DFG-IRTG 1740/2.

Edited by: Maria Assuncao Silva Dias

Reviewed by: Simone Ferraz and one anonymous referee

\section{References}

Altaratz, O., Koren, I., Yair, Y., and Price, C.: Lightning response to smoke from Amazonian fires, Geophys. Res. Lett., 37, L07801, https://doi.org/10.1029/2010gl042679, 2010.

Alvarez, M. S., Vera, C. S., Kiladis, G. N., and Liebmann, B.: Influence of the Madden Julian Oscillation on precipitation and surface air temperature in South America, Clim. Dynam., 46, 245262, https://doi.org/10.1007/s00382-015-2581-6, 2015.

Alves, L. M.: Análise estatística da sazonalidade e tendências das estações chuvosas e seca na Amazônia: clima presente e projeções futuras, Tese (Doutorado em Meteorologia) - Instituto Nacional de Pesquisas Espaciais (INPE), São José dos Campos, 166 pp., 2016.

Andreae, M. O., Rosenfeld, D., Artaxo, P., Costa, A. A., Frank, G. P., Longo, K. M., Silva-Dias, M. A. F.: Smoking rain clouds over the Amazon, Science, 303, 1337-1342, https://doi.org/10.1126/science.1092779, 2004.

Angelini, I. M., Garstang, M., Davis, R. E., Hayden, B., Fitzjarrald, D. R., Legates, D. R., Greco, S., Macko, S., and Connors, V.: On the coupling between vegetation and the atmosphere. Theor. Appl. Climatol., 105, 243-261, https://doi.org/10.1007/s00704010-0377-5, 2011.

Aragão, L. E., Poulter, B., Barlow, J., Anderson, L., Malhi, Y., Phillips, O. L., and Gloor, E.: Environmental change and the 
carbon balance of Amazonian forests, Biol. Rev., 89, 913-931, https://doi.org/10.1111/brv.12088, 2014.

Bombardi, R. J. and Carvalho, L. M. V.: IPCC global coupled model simulations of the South America monsoon system, Clim. Dynam., 33, 893-916, https://doi.org/10.1007/s00382-008-0488-1, 2009.

Butt, N., de Oliveira, P. A., and Costa, M. H.: Evidence that deforestation affects the onset of the rainy season in Rondonia, Brazil, J. Geophys. Res., 116, D11120, https://doi.org/10.1029/2010JD015174, 2011.

Cohen, J. C. P., da Silva Dias, M. A. F., and Nobre, C. A.: Environmental conditions associated with Amazonian squall lines: A case study, Mon. Weather Rev., 123, 3163-3174, https://doi.org/10.1175/15200493(1995)123<3163:ECAWAS>2.0.CO;2, 1995.

De Souza, E. B. and Ambrizzi, T.: Modulation of the intraseasonal rainfall over tropical Brazil by the Madden-Julian oscillation, Int. J. Climatol., 26, 1759-1776, 2006.

Espinoza, J. C., Ronchail, J., Guyot, J. L., Junquas, C., Vauchel, P., Lavado, W. S., Drapeau, G., and Pombosa, R.: Climate variability and extremes drought in the Upper Solimões River (Western Amazon Basin): Understanding the exceptional 2010 drought, Geophys. Res. Lett., 38, L13406, https://doi.org/10.1029/2011GL047862, 2011.

Fisch, G., Tota, J., Machado, L. A. T., Silva Dias, M. A. F., Lyra, R. F., Nobre, C. A., Dolman, A. J., and Gash, J. H. C.: The convective boundary layer over pasture and forest in Amazonia, Theor. Appl. Climatol., 78, 47-59, https://doi.org/10.1007/s00704-0040043-x, 2004.

$\mathrm{Fu}, \mathrm{R}$. and Li, W.: The influence of the land surface on the transition from dry to wet season in Amazonia, Theor. Appl. Climatol., 78, 97, https://doi.org/10.1007/s00704-004-0046-7, 2004.

Fu, R., Zhu, B., and Dickinson, R. E.: How do atmosphere and land surface influence seasonal changes of convection in the tropical Amazon?, J. Climate, 12, 1306-1321, 1999.

Fu, R., Yin, L., Li, W., Arias, P. A., Dickinson, R. E., Huang, L., Chakraborty, S., Fernandes, K., Liebmann, B., Fisher, R., and Myneni, R. B.: Increased dry-season length over southern Amazonia in recent decades and its implication for future climate projection, P. Natl. Acad. Sci. USA, 110, 18110-18115, https://doi.org/10.1073/pnas.1302584110, 2013.

Gan, M. A., Kousky, V. E., and Ropelewski, C. F.: The South America monsoon circulation and its relationship to rainfall over westcentral Brazil, J. Climate, 17, 47-66, 2004.

Gloor, M. R. J. W., Brienen, D., Galbraith, T. R., Feldpausch, J., Schöngart, W., Guyot, J. L., Espinoza, J. C., Lloyd, J., and Phillips, O. L.: Intensification of the Amazon, hydrological cycle over the last two decades, Geophys. Res. Lett., 40, 1729-1733, https://doi.org/10.1002/grl.50377, 2013.

Gonçalves, W. A., Machado, L. A. T., and Kirstetter, P.-E.: Influence of biomass aerosol on precipitation over the Central Amazon: an observational study, Atmos. Chem. Phys., 15, 6789-6800, https://doi.org/10.5194/acp-15-6789-2015, 2015.

Greco, S., Swap, R., Garstang, M., Ulanski, S., Shipman, K., Harriss, R. C., Talbot, R., Andreae, M. O., and Artaxo, P.: Rainfall and surface kinematic conditions over central Amazonia during ABLE-2B, J. Geophys. Res.-Atmos., 95, 17001-17014, https://doi.org/10.1029/JD095iD10p17001, 1990.
Hendon, H. H., Wheeler, M., and Zhang, C.: Seasonal dependence of the MJO- ENSO Relationship, J. Climate, 20, 531-543, 2007.

Huntingford, C., Zelazowski, P., Galbraith, D., Mercado, L. M., Sitch, S., Fisher, R., Loma, M., Walkenrn, A. P., Jones, C. D., Booth, B. B. B., Malhi, Y., Hemming, D., Kay, G., Good, P., Lewis, S. L., Phillips, O. L., Atkin, O. K., Lloyd, J., Gloor, E., Zaragoza-Castells, J., Meir, P., Betts, R., Harris, P. P., Nobre, C. A., Marengo, J. A., Cox, P. M.: Simulated resilience of tropical rainforests to $\mathrm{CO}_{2}$-induced climate change, Nat. Geosci., 6, 268-273, https://doi.org/10.1038/NGEO1741, 2013.

Koren, I., Altaratz, O., Remer, L. A., Feingold, G., Martins, J. V., and Heiblum, R. H.: Aerosol-induced intensification of rain from the tropics to the mid-latitudes, Nat. Geosci., 5, 118-122, https://doi.org/10.1038/ngeo1364, 2012.

Kousky, V. E.: Pentad outgoing longwave radiation climatology for the South America sector, Revista Brasilera de Meteorología, 3, 217-231, 1988.

$\mathrm{Li}, \mathrm{W}$. and Fu, R.: Influence of Cold Air Intrusions on the Wet Season Onset over Amazonia, J. Climate, 19, 257-275, 2006.

Li, W., Fu, R., Dickinson, R. E.: Rainfall and its seasonality over the Amazon in the 21st century as assessed by the coupled models for the IPCC AR4, J. Geophys. Res., 111, D02111, https://doi.org/10.1029/2005JD006355, 2006.

Liebmann, B. and Marengo, J. A.: Interannual variability of the rainy season and rainfall in the Brazilian Amazon Basin, J. Climate, 14, 4308-4318, 2001.

Liebmann, B., Kiladis, G. N., Marengo, J. A., Ambrizzi, T., and Glick, J. D.: Submonthly convective variability over South America and the South Atlantic convergence zone, J. Climate, 12, 1877-1891, 1999.

Machado, L. A. T., Silva Dias, M. A. F., Morales, C., Fisch, G., Vila, D., Albrecht, R., Goodman, S. J., Calheiros, A. J. P., Biscaro, T., Kummerow, C., Cohen, J., Fitzjarrald, D., Nascimento, E. L., Sakamoto, M. S., Cunningham, C., Chaboureau, J. P., Petersen, W. A., Adams, D. K., Baldini, L., Angelis, C. F., Sapucci, L. F., Salio, P., Barbosa, H. M. J., Landulfo, E., Souza, R. A. F., Blakeslee, R. J., Bailey, J., Freitas, S., Lima, W. F. A., and Tokay, A.: The CHUVA Project. How Does Convection Vary across Brazil?, B. Am. Meteorol. Soc., 95, 1365-1380, https://doi.org/10.1175/bams-d-13-00084.1, 2014.

Madden, R. A. and Julian, P. R.: Observations of the 40-50-Day Tropical Oscillation - A Review, Mon. Weather Rev., 122, 814837, 1994.

Magrin, G. O., Marengo, J. A., Boulanger, J. P., Buckeridge, M. S., Castellanos, E., Poveda, G., Scarano, F. R., and Vicuna, S.: Central and South America, in: Climate Change 2014: Impacts, Adaptation and Vulnerability, Contribution of Working Group II to the Fifth Assessment Report of the Intergovernmental Panel on Climate Change, Cambridge University Press: Cambridge, UK, 2014.

Makaireva, A. M., Gorshkov, V. G., Sheil, D., Nobre, A. D., and $\mathrm{Li}$, B.-L.: Where do winds come from? A new theory on how water vapor condensation influences atmospheric pressure and dynamics, Atmos. Chem. Phys., 13, 1039-1056, https://doi.org/10.5194/acp-13-1039-2013, 2013.

Marengo, J. A.: Interannual variability of surface climate in the Amazon basin, Int. J. Climatol., 12, 853-863, 1992. 
Marengo, J. A. and Espinoza, J. C.: Extreme seasonal droughts and floods in Amazonia: causes, trends and impacts, Int. J. Climatol., https://doi.org/10.1002/joc.4420, 2015.

Marengo, J. A., Liebmann, B., Kousky, V. E., Filizola, N. P., and Wainer, I. C.: Onset and end of the rainy season in the Brazilian Amazon basin, J. Climate, 14, 833-852, 2001.

Marengo, J. A., Nobre, C. A., Tomasella, J., Oyama, M. D., Oliveira, G. S., de Oliveira, R., Camargo, H., Alves, L. M., and Brown, I. F.: The drought of Amazonia in 2005, J. Climate, 21, 495-516, https://doi.org/10.1175/2007JCLI1600.1, 2008.

Marengo, J. A., Tomasella, J., Alves, L. M., Soares, W., and Rodriguez, D. A.: The drought of 2010 in the context of historical droughts in the Amazon region, Geophys. Res. Lett., 38, 1-5, 2011.

Marengo, J. A., Liebmann, B., Grimm, A. M., Misra, V., Silva Dias, P. L., Cavalcanti, I. F. A., Carvalho, L. M. V., Berbery, H., Ambrizzi, T., Vera, C. S., Saulo, A. C., Nogues Paegle, J., Zipser, E., Seth, A., and Alves, L. M.: Recent developments on the South American monsoon system, Int. J. Climatol., 32, 1-21, https://doi.org/10.1002/joc.2254, 2012.

Martin, S. T., Artaxo, P., Machado, L. A. T., Manzi, A. O., Souza, R. A. F., Schumacher, C., Wang, J., Andreae, M. O., Barbosa, H. M. J., Fan, J., Fisch, G., Goldstein, A. H., Guenther, A., Jimenez, J. L., Pöschl, U., Silva Dias, M. A., Smith, J. N., and Wendisch, M.: Introduction: Observations and Modeling of the Green Ocean Amazon (GoAmazon2014/5), Atmos. Chem. Phys., 16, 47854797, https://doi.org/10.5194/acp-16-4785-2016, 2016.

Martins, J. A., Dias, M. A. F., and Goncalves, F. L. T.: Impact of biomass burning aerosols on precipitation in the Amazon: A modeling case study, J. Geophys. Res.-Atmos., 114, D02207, https://doi.org/10.1029/2007jd009587, 2009a.

Muza, M. N., Carvalho, L. M. V., Jones, C., and Liebmann, B.: Intraseasonal and interanual variability of extreme dry and wet events over Southeastern South America and Sub- tropical Atlantic during the Austral Summer, J. Climate, 22, 1682-1699, 2009.

Pöhlker, M. L., Pöhlker, C., Ditas, F., Klimach, T., Hrabe de Angelis, I., Araújo, A., Brito, J., Carbone, S., Cheng, Y., Chi, X., Ditz, R., Gunthe, S. S., Kesselmeier, J., Könemann, T., Lavric, J. V., Martin, S. T., Mikhailov, E., Moran-Zuloaga, D., Rose, D., Saturno, J., Su, H., Thalman, R., Walter, D., Wang, J., Wolff, S., Barbosa, H. M. J., Artaxo, P., Andreae, M. O., and Pöschl, U.: Longterm observations of cloud condensation nuclei in the Amazon rain forest - Part 1: Aerosol size distribution, hygroscopicity, and new model parametrizations for CCN prediction, Atmos. Chem. Phys., 16, 15709-15740, https://doi.org/10.5194/acp-16-157092016, 2016.

Raia, A. and Cavalcanti, I. F. A.: The Life Cycle of the South American Monsoon System, J. Climate, 21, 6227-6246, 2008.

Rao, V. B., Cavalcanti, I. F. A., and Hada, K.: Annual variation of rainfall over Brazil and water vapor characteristics over South America, J. Geophys. Res., 101, 26539-26551, https://doi.org/10.1029/96JD01936, 1996.

Reutter, P., Su, H., Trentmann, J., Simmel, M., Rose, D., Gunthe, S. S., Wernli, H., Andreae, M. O., and Pöschl, U.: Aerosol- and updraft-limited regimes of cloud droplet formation: influence of particle number, size and hygroscopicity on the activation of cloud condensation nuclei (CCN), Atmos. Chem. Phys., 9, 70677080, https://doi.org/10.5194/acp-9-7067-2009, 2009.
Ronchail, J., Bourrel, L., Cochonneau, G., Vauchel, P., Phillips, L., Castro, A., Guyot, J. L., and de Oliveira, E.: Climate and inundations in the Mamoré basin (South-Western Amazon - Bolivia), J. Hydrol., 302, 223-238, 2005.

Runyan, C. W., D'Odorico, P., and Lawrence, D.: Physical and biological feedbacks of deforestation, Rev. Geophys., 50, RG4006, https://doi.org/10.1029/2012RG000394, 2012.

Salati, E. and Vose, P. B.: Amazon basin: a system in equilibrium, Science, 225, 129-138, 1984.

Shimizu, M. H., Ambrizzi, T., and Liebmann, B.: Extreme precipitation events and their relationship with ENSO and MJO phases over northern South America, Int. J. Climatol., 37, 2977-2989, https://doi.org/10.1002/joc.4893, 2016.

Silva, A. E. and Carvalho, L. M. V.: Large-scale index for South America Monsoon (LISAM), Atmos. Sci. Lett., 8, 51-57, 2007.

Spracklen, D. V. and Garcia-Carreras, L.: The impact of Amazonian deforestation on Amazon basin rainfall, Geophys. Res. Lett., 42, 9546-9552, https://doi.org/10.1002/2015GL066063, 2015.

Wang, G., Sun, S., and Mei, R.: Vegetation dynamics contributes to the multi-decadal variability of precipitation in the Amazon region, Geophys. Res. Lett., 38, L19703, https://doi.org/10.1029/2011GL049017, 2011.

Wang, H. and Fu, R.: Cross-Equatorial Flow and Seasonal Cycle of Precipitation over South America, J. Climate, 15, 1591-1608, 2002.

Wang, J., Krejci, R., Giangrande, S., Kuang, C., Barbosa, H. M., Brito, J., Carbone, S., Chi, X., Comstock, J., Ditas, F., Lavric, J., Manninen, H. E., Mei, F., Moran-Zuloaga, D., Pöhlker, C., Saturno, J., Schmid, B., Souza, R. A. F., Springston, S. R., Tomlinson, J. M., Toto, T., Walter, D., Wimmer, D., Smith, J., Kulmala, M., Machado, L. A. T., Artaxo, P., Andreae, M. O., Petäjä, T., and Martin, S. T.: Amazon boundary layer aerosol concentration sustained by vertical transport during rainfall, Nature-Letters, 539, 416-419, https://doi.org/10.1038/nature19819, 2016.

Williams, E. and Renno, N.: An Analysis of the Conditional Instability of the Tropical Atmosphere, Mon. Weather Rev., 121, 21-36, 1993.

Williams, E., Dall'Antonia, A., Dall'Antonia, V., de Almeida, J., Suarez, F., Liebmann, B., and Malhado, A. C. M.: The drought of the century in the Amazon basin: an analysis of the regional variation of rainfall in South America in 1926, Acta Amazonia, 35, 231-238, https://doi.org/10.1590/S004459672005000200013, 2005.

Yoon, J. H. and Zeng, N.: An Atlantic influence on Amazon rainfall, Clim. Dynam., 34, 249-264, https://doi.org/10.1007/s00382009-0551-6, 2010.

Zhang, Y., Fu, R., Yu, J., Qian, Y., Dickinson, R., Silva Dias, M. A. F., da Silva Dias, P. L., and Fernandes, K.: Impact of biomass burning aerosol on the monsoon circulation transition over Amazonia, Geophys. Res. Lett., 36, L10814, https://doi.org/10.1029/2009GL037180, 2009. 